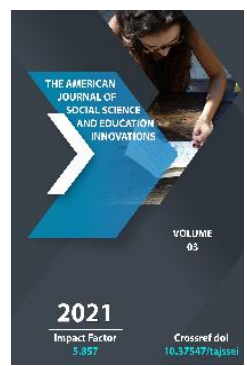

\title{
Sound Capabilities In Traditional Performance
}

\author{
Utkir Tugulov
}

Teacher, Department Of “Music Education”, Jizzakh State Pedagogical University, Uzbekistan

Copyright: Original content from this work may be used under the terms of the creative commons attributes 4.0 licence.

\section{ABSTRACT}

This article describes the unique ways in which the sound possibilities of traditional performance affect all branches of the art of memorization in traditional performance.

\section{KEYWORDS}

Memorization, criterion, tradition, ritual, dignity, perfection, interpretation, sound, laughter, fake performer, listener, falsetto.

\section{INTRODUCTION}

The art of music is revered as one of the defining criteria of human spirituality, rich worldview and future perfection. The national traditions, customs, ceremonies and values of each nation have a worthy place in it. Among the directions, the art of memorization is one of the oldest, formed as one of the branches that has matured in practical experience and has really achieved perfection in the process of practice. Hafiz is imbued with features that affect all branches of the musical art equally and are exemplary and exemplary. That is why it is safe to say that the art of hafiz is a complex, orderly, structured, based on certain laws, and, of course, has its own traditions. The formation and development of all this is the result of a live 
process of "performance", that is, the melody of music, which demonstrates the power and magic of music.

\section{THE MAIN FINDINGS AND RESULTS}

The fact that the singers are impeccable until the end of their performance and fully maintain their level and ability is due to a number of performance and physical conditions. This is called "uniform maintenance" in athletes and is monitored during regular exercise. One of the things that singers need to keep under control is to preserve the sound that nature gives them. Second, there is a strong emphasis on the properties of sound, and third, adherence to the laws of talc. Sound capabilities are usually the process that forms the basis of music. Sound is an appearance. It can be achieved by various means and actions. The fact that the sounds have a certain pitch is a musical sound. First of all, the human voice is able to sing the sounds of music perfectly through meaning and emotion. The singer's voice has a timbre that is created by the strength of the voice, the pitch, the loudness, and the harmony of it all. In the traditional art of Uzbek singing, however, there is a tone of voice, mungi, dardi, bezagi, xirgoyi, which has no appearance, but is felt in the senses, and has a full meaning. constitutes the desired sound. For example, in the practice of classical singing, these features have been positively assessed as passionate features of performance.

Taking full advantage of all the structural features of the voice, using all its possibilities, creative approach and the ability to influence the heart of the listener is a unique interpretation of the representatives of classical singing. After all, every singersongwriter (performer) has an impact on the spiritual nourishment of the audience.
It is clear that the human voice has its own defining characteristics. While some of these are related to natural talent, it should be noted that some are formed in the course of lessons, exercises and experiences.

There are many types of sounds in the practice of traditional Uzbek singing. They are named by professional singers because of their features and qualities. For example: "High voice", "Davudiy voice”, "Strong voice", "Puet voice", "Ill voice”, "A painful voice”, "Mucos Voice", "Tired voice", "Yelling Voice", "Sadcrying voice", etc. The voice of the singer is characterized not only by their features, but also by the range of performance. Vowels can be divided into low and high registers. Typically, the concept of register is part of the sound range.

Researcher D.Mullakandov conducts scientific research on the technique of using musical sounds based on his experience. Based on this, he reveals the distinctive sound features of Uzbek national singing and calls them "traditional styles of singing". In this study, the author divides traditional singing into 3 types of sound methods. That is, "Binnigi" (nostril), "Guligi" (throat) and "Ishkami" (korin) [1, p. 1923], and each method has its own scientific and theoretical description. It should be noted that in Uzbek singing, another voice, the chest voice, is also very popular.

It is known that in singing, the way of utterance is formed as a result of the interdependence and proper use of the vocal, respiratory and vocal apparatus. According to the author's definition, "binnigi" is an artificial method of performance, in which voices are combined and mainly sounded in the dim. The "guligi" method is widespread in all oases of Uzbekistan, and in the process of performance 
it is necessary to use artificial methods, such as powering the singer's throat, difficult interpretation, vague expression of words, amplifying the voice, decoration. The Ishkami method, according to the author, is the most pleasant and high-quality performance among the peoples of Central Asia. This category of performers has a deep breath, a strong timbre, a louder, clearer and lighter voice over a wide range.

In addition to the three methods, the technique of sound interpretation in the traditional Uzbek art of singing is the "falset method", which is common in the practice of great singers and performers". There is also a specific use of sounds. It should be noted that the falsetto sound interpretation is widely used by Uzbek singers and varies in Uzbek tones.

Singing sound interpretation is divided into low, medium and high registers. The upper bouts featured two cutaways, for easier access to the higher frets. The falsetto is also a fake sound that is consciously artificially sung. Falset has been used in almost all singing industries, depending on the opportunity and the skill. In fact, it is common for fake voices to be combined with real voices. In Uzbek classical singing, falsetto is widely used in various forms.

A falsetto is usually an artificial sound that results from the falsetto singer's natural sound capabilities. This method is widely used in Western music culture, in vocal singing. In the Uzbek master's interpretation of music, the falsetto is used in a unique way. This method, which is used in a certain part of the work in the European art of singing, has a worthy place in the interpretation of singers from the oases of Uzbekistan, especially from the Khorezm and Fergana-Tashkent performance lines. In the process of execution, the falset appears in various forms. Typically, most singers use this technique in part, using the falsetto to perform the climax of the piece [2]. The "falset" method is widely used in the performance of Uzbek music, especially in the practice of performing masterpieces (maqoms).

Some singers are unable to interpret the climax of the song, the highest scenes, with a natural voice, and in such cases sing with a falsetto voice. When using the falsetto method, the singer must masterfully perform the sound exchange factor. His skill is reflected in the fact that he does not notice the difference between artificial sound from natural sound in the process of performance and uses the method wisely.

It is well known that the art of music performance is characterized by a large number of methods associated with the interpretation of the performance, stability and interconnectedness. Certain aspects of the Uzbek music performance tradition also need to be interpreted in this direction.

Classical music has a number of traditional qualities. In the process of interpretation, it is inevitable that the sound will be loud, low, exaggerated, pampered, forced or completely empty, and the method will be interpreted in an orderly manner. Simply put, it's dynamic. In the falsetto method, the performer uses certain points and sentences to ensure the dynamic development of the work. Typically, this style is found in the components of the work, such as income, advance, miyonhat, dunasr, avj, great avj. Slow, low-pitched parts of the song have been performed in this way.

There are many aspects of the art of singing in the oases of Uzbekistan, each of which is a different world. The falsett's combination with 
classical singing can be seen in the performances of Fergana-Tashkent (singing and big singing), especially in the performances of the Khorezm oasis Komiljon Otaniyozov, Ruzimat Jumaniyazov, Kuvondik Iskandarov, Rakhmatjon Kurbanov.

The above-mentioned and the three-way performers have long been active in all local areas. This factor is characteristic not only of a particular performer, but also of local, as well as Uzbek music genres. While the genre's features are associated with the performance of epics, maqoms, great songs, and water samples, their popularity and traditions are imbued with oasis.

In particular, it is incorrect to say that there is only one style of singing based on the performance traditions of Uzbek classical hafiz. Because the process of performing our musical heritage, which is worthy of the oral tradition, depends on the specific conditions, the place. At the same time, the representatives of the art of music acted as promoters of a number of genres. In most cases, attempts have been made to perform works of composers and composers, works imbued with the spirit of the times, typical of the musical art of time and space. Therefore, master musicians need to know two or three singing styles and be able to use them appropriately in order to find a suitable system of features such as intensity, pleasure, high timbre, badihaguylik and design in the interpretation of musicians. Because each style of singing has its own pros and cons. Taking advantage of their positive qualities shows their effectiveness in performance. At the same time, the internal features of musical samples, the process of development, the nature (dynamics), the intensity require the use of these features to some extent. Here, in the tradition of classical music performance, master singers have widely used the style of singing "guligi" and "ishkami". The most important factor for performers working in the field of sound is the direct interpretation. Performance Interpretation - can indicate any level of performance based on the performer's qualifications, experience, and skill. This criterion, of course, depends on the interpretation of the sound. Because sound is interpreted in different contexts and situations. It has a special impact on the performer's mental state, health, readiness of the voice to perform, the place of the place, the listener and the repertoire, each in its own direction. The performer can simply sing the singer's voice. Or it can be interpreted in a decorative, that is, soft, delicate, embellished way, adding as much pain as necessary, adding sorrow if necessary, giving a meaningful and meaningful, philosophical tone. Therefore, this process plays an important role in the interpretation of the work (level of performance), the disclosure of the inner and outer world (the essence of the performance) and the harmonization of its structural aspects in accordance with the genre (performance order).

As noted above, direct voice interpretation also typically occurs in three forms in executive practice. Simply execution (indifferent), imitation, and personal (permanent) execution. That is, performers who take care of their voices in every way, master the best aspects of different performance styles, and achieve personal interpretation based on constant research and development.

In most cases, in the practice of mastery performance, the last category of singers is to create more eye-catching performance styles, to create independently, to contribute to the 
steady development of the musical heritage. achieved. At the same time, they laid the groundwork for the continuation of their schools of performance in later periods. In his research, musicologist Yu.V. Katz defines this factor as the "difficulty of interpretation" and notes that the factors that characterize it are related to four conditions. "... the interpreter's (i.e., singer's) personal abilities (e.g., natural abilities such as hearing ability, musical memory, volume of voice, level of lesson and knowledge, etc.), perceptual norms ..." [3, p. 109]. These aspects of course, it should be noted that the singer included problems with the level of performance.

Performing arts are a reflection of human spirituality. The artist is the creator, custodian, successor and future of this mirror. Whichever nation is great, its art and artist will be great and unique. In this regard, it should be noted that the Uzbek musical art is ancient and rich, multifaceted and constantly evolving with the times. The creators and performers of the rich musical heritage are the corresponding great musicians and singers. They have been cherished throughout history and passed down from generation to generation. The role of singers in society, as well as their status, attitude to the audience, their behavior, behavior, performance and performance repertoire have been showing the secret.

\section{CONCLUSION}

Singers have long been revered as a respected figure of the people. Many of them have the name "Haji" added to their names. There are several reasons for this. First of all, this is due to the fact that they performed the deeds of the name, and secondly, because the hafiz were aware of a number of sciences. The Hafiz acted as an example to all in the eyes of the people. Because we've outlined the criteria for that. The performance process itself requires them to be as polite, moral, delicate, gentle, beautiful, graceful, and sincere as they are in the brochure in walking, standing, sitting, dressing, performing, and treating the listener. All of these are peculiarities of the singer's performance culture. In particular, it is incorrect to say that the Uzbek classical hafiz tradition is based on a single singing style. Because the process of performing our musical heritage, which is worthy of the oral tradition, depends on the specific conditions, the place. At the same time, the representatives of the art of music acted as promoters of a number of genres. In most cases, attempts have been made to perform works of composers and composers, works imbued with the spirit of the times, typical of the musical art of time and space. Therefore, master musicians need to know two or three singing styles and be able to use them appropriately in order to find a suitable system of interpretation, such as intensity, pleasure, high timbre, charm and design. . Because each style of singing has its own pros and cons. Taking advantage of their positive qualities shows their effectiveness in performance. At the same time, the internal features of musical samples, the process of development, the nature (dynamics), the intensity require the use of these features to some extent. Here, in the tradition of classical music performance, master singers have widely used the methods of singing "guligi" and "ishkami". Performance Interpretation can represent any level of performance based on the performer's qualifications, experience, and skills. This criterion, of course, depends on the level of interpretation. Because sound is interpreted in different contexts and situations. It has a special effect on the mood of the performer, his health, the readiness of 
his voice to perform, the place of the place, the listener and the repertoire, each in its own direction. The performer can simply sing the singer's voice. Or it can be interpreted in a decorative, that is, soft, delicate, embellished way, adding as much pain as necessary, adding sorrow if necessary, giving a meaningful and meaningful, philosophical tone. Therefore, this process plays an important role in the interpretation of the work (level of performance), the disclosure of the inner and outer world (the essence of the performance) and the harmonization of its structural aspects in accordance with the genre (performance order).

\section{REFERENCES}

1. D. Mullakandov. (1959) “On some features and types of Uzbek national singing" // Folk musicians of Uzbekistan. - Tashkent. "State Edition". - pp. 19-23. (Д.Муллакандов. «О некоторых особенностях и видах узбекского национального пения» //Народные музыканты Узбекистана. Т., «Гос. изд.» 1959 г. с.19-23.)

2. The falcet method can be imagined in the performance of the well-known singer Tavakkal Kadyrov. However, it should be noted that this singer sings the falcett in accordance with the Uzbek method of "tanglay orti ovozi". As a result, the voice sounds strong and eloquent. (Фальцет усулини, айни пайтда таниқли хонанда Таваккал Қодиров ижроси мисолида тасаввур этиш мумкин. Лекин, қайд этиш жоизки бу хонанда фальцет ижро усулини ўзбекона «танглай орти овози» усули билан уйгун холда тараннум этади. Натижада овоз кучли ва забардаст киёфада янграйди.)
3. Yu.V. Kats. (1986) "Basics of Modeling the Formation of Musical Analysis". Tashkent. - p. 109. (Ю.В.Кац. «Основы моделирование формирования музыкального анализа». Т., 1986 г. с.109.)

4. I.A.Karimov. (2008) High spirituality is an invincible force. - Tashkent. "Ma'naviyat" publishing house. (И.А.Каримов. Юксак маънавият-енгилмас куч. -Т.: “Маънавият” нашриёти. 2008-йил.)

5. O.Q.Qolipov, M.Usmonboeva. (2006) Applied bases of pedagogical technologies. - Tashkent. “Fan” publishing house. (Ў.қ.Толипов, М.Усмонбоева. Педагогика технологияларнинг тадбиқий асослари. -Т.: “Фан” нашриёти. 2006йил.)

6. V.N. Maksimov. ( 1988) Interdisciplinary communication in the learning process. Moscow:

“Enlightenment". (В.Н.Максимова. Межпредметные связи В процессе обучения. -М.: “Просвишение”. 1988-год.)

7. T.E.Solomonova. (1981) History of Uzbek music. - Tashkent. "Teacher" publishing house. (Т.Е.Соломонова. Ўзбек мусиқаси тарихи. -Т.: “Ўқитувчи” нашриёти. 1981йил.)

8. I.Rajabiy. (1963) On the issue of status. Tashkent. "Fiction" publishing house. (И.Ражабий. Мақомлар масаласига доир. -Т.: “Бадиий адабиёт” нашриёти. 1963йил.)

9. I.Qudratov, E.Abdukarimova. (2015) Interdisciplinary Relationships in Music Education. Methodological manual. Samarkand, SamSU printing house. (I.Qudratov, E.Abdukarimova. "Musiqa ta'limida fanlararo aloqadorlik". Uslubiy qo'llanma. Samarqand, SamDU bosmaxonasi, 2015yil.) 
10. E.Abdukarimova."Preparation of future music teachers for their professional activities through uzbekclassicall music" European Journal of Research and Reflection in Educational Sciences. Volume 7 Number 6, 2019 ISSN 2056-5852

11. E.Abdukarimova. Science is also the subject of "Technological design - effective education in music lessons" at the Nukis State Pedagogical Institute. 2019 (№1) ISSN 2010-720X (E.Abdukarimova. Ilm ham jamiyet ajiniyaz atindagi Nokis mamleketlik pedagogikaliq institute "Texnologik loyihalash- musiqa mashg'ulotlarida samarali ta'lim”. 2019 (№1) ISSN 2010$720 X)$

12. Elnoza Ismatillayevna Abdukarimova. (2017) Actual challenges of modern science. "People's musical heritage is a powerful educational tool in educating the younger generation in the national spirit" sciences. (Elnoza Ismatillayevna Abdukarimova Актуальные вызовы современной науки. "Yosh avlodni milliy ruhda tarbiyalashda xalq musiqa merosi qudratli tarbiya vositasi" iscience 2017 йилги)

13. The concept of music education and upbringing in secondary schools. Tashkent. MPE, 1995. (Umumta'lim maktablarida musiqa ta'limi va tarbiyasi Konsepsiyasi. - Toshkent, XTV, 1995 yil.)

14. Hasanov A. (1993) Music and education. Tashkent. Teacher. (Hasanov A..Musiqa va tarbiya. -T.: O'qituvchi, 1993.)

15. Kudratov I. (2009) Aesthetic education of students through folk songs. - Tashkent: Fan. (Qudratov I. Talabalarni xalq qo'shiqlari vositasida estetik tarbiyalash. Toshkent: Fan, 2009.)

16. Fayzullayev E. (2010) Uzbek classical music is a factor in shaping students' artistic taste. - Tashkent. Center for Education and Technology Publishing House. (Fayzullayev E. O'zbek mumtoz musiqasi talabalarning badiiy didini shakllantirish omili. Toshkent: Ta'lim va texnalogiyalar markazi nashriyoti, 2010.) 